https://www.sworldjournal.com/index.php/swj/article/view/swj06-01-048 DOI: 10.30888/2663-5712.2020-06-01-048

\title{
УДК 641.85:613.292
}

\section{QUALITY OF DESSERTS USING DIETARY SUPPLEMENT «MIPRO-VIT» WITH PHYSICAL WELL-BEING PURPOSE ЯКІСТЬ ДЕСЕРТІВ ІЗ ВИКОРИСТАННЯМ ДІЕТИЧНОЇ ДОБАВКИ «МІПРО-ВІТ» ОЗДОРОВЧОГО ПРИЗНАЧЕННЯ}

Peresichna S. M. / Пересічна C. М. c.t.s., as.prof. / к.m.н., доu. ORCID: 0000-0003-2023-558X

Kyiv National University of Culture and Arts, Kyiv,Konovalets, 36, 01133 Київський національний університет культури і мистецтв, Київ, Коновальия, 36, 01133

Анотація. Підвищення харчової изіності десертних страв можна здійснювати за рахунок регулювання хімічного складу сировини та введенням дієтичних добавок. У статті розглядаються шляхи покращення якості десертних страв за рахунок використання у шоколадному фондані дієтичної добавки «Міпро-ВIТ». Вивчивши вплив дієтичної добавки «Міпро-ВIT» на органолептичні властивості десерту, виявлено збагачення мінерального, вітамінного складу, а також білків у страві. I як наслідок, покращення харчової циінності продукту. Проаналізувавши отримані дані з розрахунку комплексного показника якості шоколадного фондану з дієтичною добавкою «Міпро-ВIT», можна стверджувати, шчо розроблена десертна страва має більш високий комплексний показник якості, ніж контрольний зразок: контроль - 0,44, дослід-0,68.

Ключові слова: якість, десерт, технологія, шоколадний фондан, дієтична добавка «Minpo-BIT».

Ветуп.

Значну питому вагу в продукції закладів ресторанного господарства посідають десертні страви. Вони мають привабливий зовнішній вигляд, приємний смак та аромат, відрізняються високою калорійністю і користуються попитом серед населення. Водночас слід пам'ятати, що часте споживання десертних страв може призвести до збудження інсулярного апарату підшлункової залози, що може спричинити иï розлади i підвищує ризик виникнення цукрового діабету. Оскільки вуглеводи, що містяться в десертних стравах, складають 75\% сухих речовин. В основному це глюкоза, фруктоза, сахароза, крохмаль.

Асортимент десертних страв досить широкий, проте необхідно вдосконалювати їх технологію, наділяючи необхідними функціональними властивостями. Одним із важливих питань вдосконалення технології десертних страв $є$ підвищення їх харчової цінності та якості з одночасним зниженням калорійності.

\section{Основний текст.}

В закладах ресторанного господарства великим попитом у широкого контингенту споживачів різних вікових категорій користується гаряча десертна страва «Шоколадний фондан» 3 наявністю рідкої начинки в середині шоколадного крему ганаш.

Шоколадний фондан готується 3 таких інгредієнти, як шоколад, борошно, какао-порошок, вершкове масло, яйця, вершки. Основною сировиною у 
технології приготування цього десерту є шоколад, що позитивно впливає на споживачів, завдяки вмісту триптофану, амінокислоти, що, потрапляючи разом 3 їжею до організму людини, переходить у серотонін, який називають «гормоном щастя». Серотонін відіграє важливу роль в здійсненні певних функцій і реакцій організму, таких як сон, настрій, поведінка. В останні роки серотонін придбав популярність за його роль у лікуванні психічних захворювань, таких як депресія [1]. Проте, шоколад багатий і жирами, а значить i калоріями. Це потребує подальшого вдосконалення технологічного процесу виробництва шоколадного фондану із застосуванням дієтичних добавок.

Обрана десертна страва є об'єктом дослідження, оскільки технологічний процес теплової обробки становить 480-600 сек., що забезпечує відносно високий вміст поживних речовин, якими може бути збагачена дана страва. При споживанні 100 г шоколадного фондану організм отримує до 12\% добової потреби у білках, біля 18\% - у вуглеводах, 12\% - у вітамінах групи В.

У сучасному житті все більше уваги приділяють оздоровчому харчуванню, збагаченому мінеральними речовинами, амінокислотами, вітамінами, яке б було соціально доступним та збалансованим. Для виробництва десертних страв підвищеної якості актуальним є використання дієтичних добавок, серед яких останнім часом все більш популярними $\epsilon$ інгредієнти на основі грибної сировини. Зважаючи на це, особливу увагу серед науковців: Антоняк Г. Л, Бабич Н.О., Дудка I. О. [2], Дорофєєв Д.О. [3] та ін. здобув лікарський гриб Fusarium sambucinum Fuckel var. ossicolum.

«Міпро-ВIT»- це натуральний рослинний продукт, який виробляється біотехнічним шляхом - вирощуванням біомаси лікарського гриба в стерильних умовах та досконалого контролю всього процесу, починаючи від контролю вхідної сировини до отримання готової добавки.

«Міпро-ВІТ» містить легкозасвоюваний білок, вуглеводи, хітинову клітковину, замінні і незамінні амінокислоти, ліпіди, нуклеїнові, органічні кислоти, фосфоліпіди, убіхінони (Q9, Q10), біологічно-активні полісахариди, вітаміни та мінерали в легкозасвоюваній органічній формі. Хітинова клітковина сорбує токсини і шлаки; біологічно активні полісахариди (глікани) регулюють роботу імунної системи.

До складу білкових компонентів дієтичної добавки входять усі незамінні амінокислоти, які не синтезуються організмом людини й повинні надходити у готовому вигляді. Жирнокислотна фракція дієтичної добавки складається 3 ненасичених жирних кислот, які необхідні організму людини. До складу препарату входить набір мінеральних речовин у легкозасвоюваній формі.

«Міпро-ВIT» не містить холестерину, не викликає побічної дії і не має протипоказань та має наступний хімічний склад (табл. 1).

У зв’язку з тим, що у природі не існує харчових продуктів, які б містили всі ессенціальні речовини, тому доречно здійснювати комбінацію різних харчових продуктів, які краще за все можуть забезпечити організм необхідними поживними речовинами.

Об’єкт дослідження: технологія та якість шоколадного фондану підвищеної харчової цінності з використанням дієтичної добавки «Міпро-ВІТ». 
Предмет дослідження: шоколадний фондан, дієтична добавка «Міпро-ВIT» (ТУ 15.8-24891340-001-2001); шоколадний фондан 3 дієтичною добавкою «Міпро-Віт».

Таблиця 1

Хімічний склад «Міпро-ВІТу»

\begin{tabular}{|l|c|}
\hline \multicolumn{1}{|c|}{ Показники } & Вміст, \% \\
\hline Сирий протеїн & $44-51$ \\
\hline Білок & $31-36$ \\
\hline Вуглеводи & $21-23$ \\
\hline Ліпіди & $6-8$ \\
\hline Нуклеїнові кислоти & $4-6$ \\
\hline Мінеральні речовини & $8-10$ \\
\hline Вітаміни & 2 \\
\hline
\end{tabular}

Джерело: [4]

Методи дослідження: органолептичні, фізико-хімічні, математичностатистична обробка експериментальних даних з використанням комп’ютерних технологій.

У процесі експериментальних досліджень розроблено технологію шоколадного фондану 3 дієтичною добавкою «Міпро-ВIT» та доведено, що раціональною кількістю дієтичної добавки є 10\% замість пшеничного борошна на 100 г готової страви, що дозволило збагатити десертну страву білками, мінеральними речовинами, вітамінами та антиоксидантами.

При проведенні дегустації десертної страви групою експертів визначено, що органолептичні показники дослідного зразка змінюються неістотно (контроль - 4,90; дослід - 4,95 балів).

Харчова цінність десертної страви 3 використанням дієтичної добавки «Міпро-ВIT» зросла за такими показниками: білків на $67 \%$; харчових волокон на 200\%; цинку - у 7,1 рази; кальцію - у 6,8 разів; заліза - на 203,1\%; фосфору на $111,7 \%$, вітамінів: $\mathrm{B}_{1}$ - на 183,3\%, $\mathrm{B}_{2}$ - на 428,5\%, РP - на 168,8\% (табл. 2).

При споживанні шоколадного фондану 3 «Міпро-ВІТом» задоволення добової потреби у білках становить $19,5 \%$; кальції - 34,1\%; фосфорі - 40,5\%; вітаміні $\mathrm{B}_{2}-41,2 \%$; вітаміні РP - 24,2\%. На основі органолептичної оцінки, кількості білків, мінерально-вітамінного комплексу, енергетичної цінності розраховано комплексний показник якості шоколадного фондану (табл. 3).

Проаналізувавши отримані дані 3 розрахунку комплексного показника якості десертів, можна стверджувати, що розроблений шоколадний фондан 3 «Міпро-ВІТом» має більш високий комплексний показник якості, ніж контрольний зразок: контроль - 0,44, дослідний зразок - 0,68.

Згідно розрахованих показників якості побудовано модель якості десертної страви (рис. 1).

Модель якості десертної страви свідчить про поліпшення якості шоколадного фондану з використанням дієтичної добавки «Міпро-ВIT». 
Таблиця 2

Харчова цінність шоколадного фондану з «Міпро-ВІТом», на 100г виробу

\begin{tabular}{|c|c|c|c|c|c|c|c|}
\hline Показники & $\begin{array}{c}\text { Добова } \\
\text { потреба }\end{array}$ & Контроль & $\begin{array}{c}\text { Забезпечення } \\
\text { добової потреби, \% }\end{array}$ & Дослід & $\begin{array}{c}\text { Забезпечення } \\
\text { добової потреби, \% }\end{array}$ & Різниця, г & $\begin{array}{c}\text { Дослід/ } \\
\text { контроль, \% }\end{array}$ \\
\hline Білки, г & 83 & 9,7 & 10,1 & 16,2 & 19,5 & 6,5 & 67,0 \\
\hline Вуглеводи, г & 205 & 37,0 & 18,1 & 42,1 & 20,5 & 5,1 & 13,0 \\
\hline Харчові волокна, г & 20 & 3,0 & 15,0 & 9,0 & 45,0 & 6,0 & 200,0 \\
\hline \multicolumn{8}{|c|}{ Мінеральні речовини } \\
\hline Калій, мг & 2500 & 180,9 & 7,2 & 367,9 & 14,7 & 186,0 & 103,3 \\
\hline Кальцій, мг & 1000 & 43,3 & 4,3 & 341,3 & 34,1 & 298,0 & 6,8 раз \\
\hline Магній, мг & 400 & 52,9 & 13,2 & 82,9 & 20,7 & 30,0 & 56,6 \\
\hline Фосфор, мг & 800 & 153,0 & 19,1 & 324 & 40,5 & 171,0 & 111,7 \\
\hline Залізо, мг & 18 & 3,2 & 17,8 & 9,7 & 53,9 & 6,5 & 203,1 \\
\hline Цинк, мг & 12 & 0,5 & 4,4 & 4,3 & 35,9 & 3,8 & 7,1 раз \\
\hline \multicolumn{8}{|c|}{ Вітаміни } \\
\hline Токоферол (Е), мг & 15 & 0,7 & 4,6 & 1,7 & 11,3 & 1,0 & 141,4 \\
\hline Тіамін (B1), мг & 1,5 & 0,06 & 4,1 & 0,2 & 11,4 & 0,1 & 183,3 \\
\hline Рибофлавін (B2), мг & 1,8 & 0,14 & 7,8 & 0,7 & 41,2 & 0,6 & 428,5 \\
\hline $\begin{array}{ll}\text { Пантотенова кислота } \\
\text { (B5), мг }\end{array}$ & 5 & 0,6 & 11,9 & 0,7 & 14,9 & 0,2 & 23,3 \\
\hline Ніацин (РP), мг & 20 & 1,8 & 9,2 & 4,8 & 24,2 & 3,0 & 168,8 \\
\hline Кальциферол (D), мкг & 10 & 1,3 & 12,7 & 2,3 & 22,7 & 1,0 & 80,2 \\
\hline $\begin{array}{l}\text { Енергетична цінність, } \\
\text { Ккал }\end{array}$ & 2500 & 464,7 & 18,5 & 509,2 & 20,4 & 44,5 & 9,6 \\
\hline
\end{tabular}

Авторська розробка 
Таблиця 3

Комплексний показник якості шоколадного фондану

\begin{tabular}{|c|c|c|c|c|c|c|c|c|}
\hline \multirow{2}{*}{ Показник якості } & \multirow{2}{*}{$\begin{array}{c}\text { Коефіцієнт } \\
\text { вагомості, } \\
\text { m } \\
\end{array}$} & \multirow{2}{*}{$P_{\text {iет }}$} & \multicolumn{3}{|c|}{ Контроль } & \multicolumn{3}{|c|}{ Дослід } \\
\hline & & & $\mathrm{P}_{\mathrm{i}}$ & $\mathrm{q}_{\mathrm{i}}$ & $\mathrm{Q}_{\mathrm{ij}}$ & $\mathrm{P}_{\mathrm{i}}$ & $\mathrm{q}_{\mathrm{i}}$ & $\mathrm{Q}_{\mathrm{ij}}$ \\
\hline $\begin{array}{l}\text { Органолептична } \\
\text { оцінка, бали }\end{array}$ & 0,3 & 5 & 5,00 & 1,00 & 0,30 & 4,90 & 0,98 & 0,29 \\
\hline Вміст білків & 0,25 & 80 & 9,70 & 0,12 & 0,03 & 16,20 & 0,20 & 0,05 \\
\hline $\begin{array}{l}\text { Енергетична } \\
\text { цінність }\end{array}$ & 0,08 & 2500 & 464,70 & 0,19 & 0,01 & 509,20 & 0,20 & 0,02 \\
\hline \multicolumn{9}{|c|}{ Мінерально-вітамінний комплекс } \\
\hline Кальцій & 0,06 & 35 & 4,33 & 0,12 & 0,01 & 34,13 & 0,98 & 0,06 \\
\hline Фосфор & 0,08 & 45 & 19,13 & 0,43 & 0,03 & 40,50 & 0,90 & 0,07 \\
\hline Залізо & 0,08 & 60 & 17,77 & 0,30 & 0,02 & 53,88 & 0,90 & 0,07 \\
\hline Рибофлавін (B2) & 0,08 & 50 & 7,83 & 0,16 & 0,01 & 41,17 & 0,82 & 0,07 \\
\hline Ніацин (РР) & 0,07 & 25 & 9,21 & 0,37 & 0,03 & 24,21 & 0,97 & 0,07 \\
\hline $\begin{array}{l}\text { Комплексний } \\
\text { показник якості, } \\
\text { од. }\end{array}$ & & & & & 0,44 & & & 0,68 \\
\hline
\end{tabular}

Авторська розробка

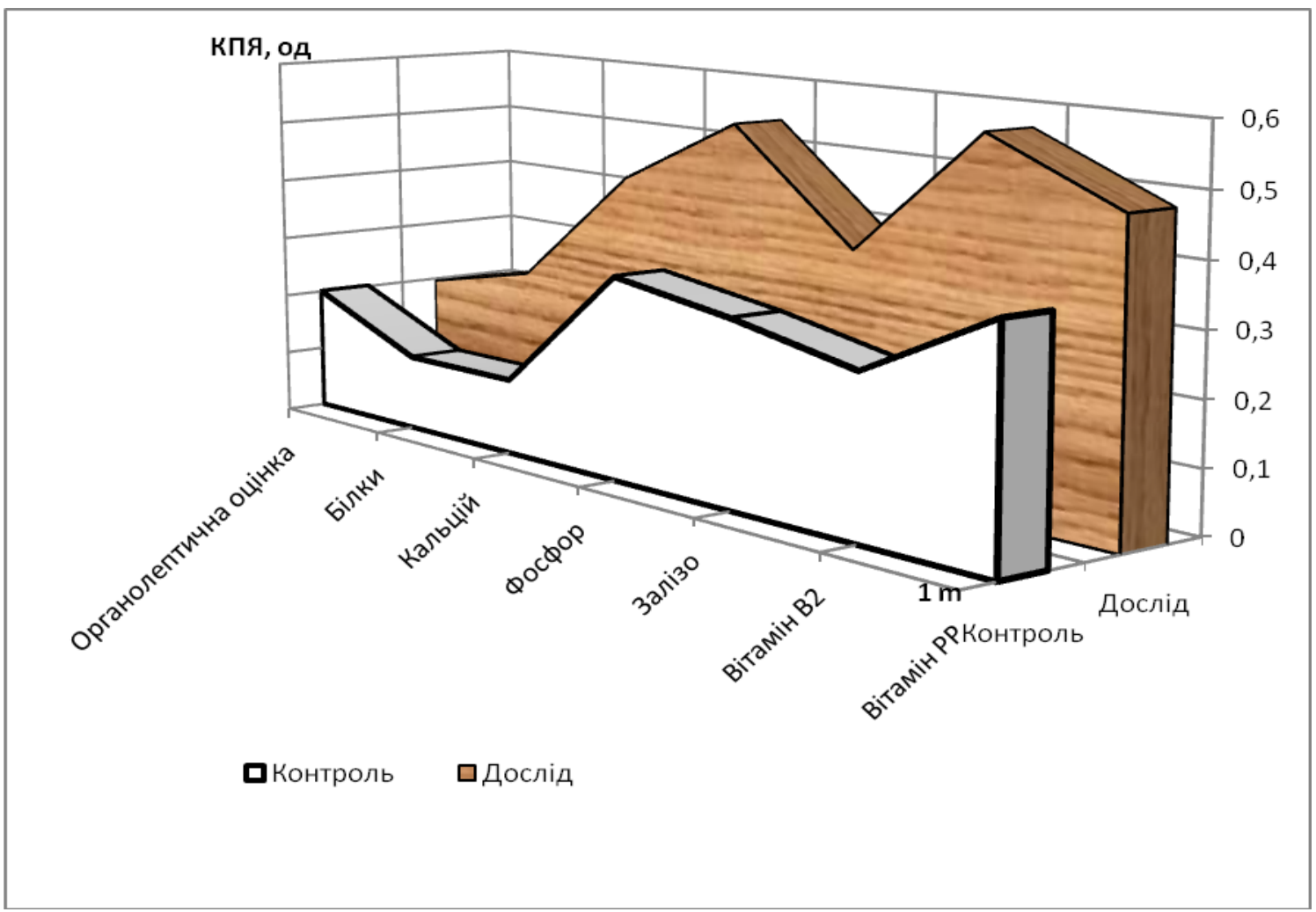

\footnotetext{
Рис. 1. Модель якості шоколадного фондану з дістичною добавкою «Міпро-BIT»
}

Авторська розробка 


\section{Висновки.}

Резюмуючи вище викладене, можна констатувати, що використання дієтичної добавки «Міпро-ВIT» в технології десертної страви сприяє отриманню шоколадного фондану підвищеної харчової цінності, яка задовольняє $11,3 \ldots 40,5 \%$ добової потреби в макро- і мікронутрієнтах.

Впровадження розробленої десертної страви із «Міпро-ВIТом» у закладах ресторанного господарства дозволить розширити асортимент продукції 3 оздоровчими властивостями, сприятиме покращенню харчування населення та загальному зміцненню організму людини до несприятливих факторів зовнішнього середовища.

\section{Література:}

1. Василенко П.В. Випускний кваліфікаційний проект. Технологія гарячих десертів підвищеної харчової цінності. URL.: $\quad$ htei.kh.ua:8080/bitstream/123456789/198/1/Василенко\%20П..pdf (дата звернення : 4.12.2020).

2. Антоняк, Г.Л., Калинець-Мамчур, 3.І., Дудка, I.О., Бабич, Н.O., Панас, Н.Є. (2013). Екологія грибів [Монографія]. Львів: ЛНУ імені Івана Франка. - 628 с.

3. Дорофеев, Д.А.Изучение антипатогенной активности гриба Fusarium sambucinum AF-967: тема диссертации и автореферата канд. биол. наук по ВАК РФ 06.01.11: https://www.dissercat.com/content/izuchenie-antipatogennoiaktivnosti-griba-fusarium-sambucinum-af-967 (дата звернення : 12.12.2020).

4. Сибірцева, I., Бондар, I., Перегуда, М. Добавки «Міш-O-Ш». URL.: http://dspace.nuft.edu.ua/jspui/bitstream/123456789/4530/1/minprov.pdf (дата звернення : 8.12.2020).

\section{References:}

1. Vasy`lenko P.V. Vy`puskny`j kvalifikacijny`j proekt. Texnologiya garyachy`x desertiv pidvy`shhenoyi xarchovoyi cinnosti.

URL: htei.kh.ua:8080/bitstream/123456789/198/1/Vasy 'lenko\%20P..pdf (data zvernennya : 4.12.2020).

2. Antonyak, G.L., Kaly`necz'-Mamchur, Z.I., Dudka, I.O., Baby`ch, N.O., Panas, N.Ye. (2013). Ekologiya gry`biv [Monografiya]. L’viv: LNU imeni Ivana Franka. - 628 s.

3. Dorofeev, D.A.Y'zucheny`e anty patogennoj akty`vnosty`gry ba Fusarium sambucinum AF-967: tema dy'ssertacy'y' $y^{\prime}$ avtoreferata kand. by'ol. nauk po VAK RF 06.01.11: https://www.dissercat.com/content/izuchenie-antipatogennoi-aktivnosti-griba-fusariumsambucinum-af-967 (data zvernennya : 12.12.2020).

4. Sy`birceva, I., Bondar, I., Pereguda, M. Dobavky http://dspace.nuft.edu.ua/jspui/bitstream/123456789/4530/1/minprov.pdf 8.12.2020).

Abstract. Increasing the nutritional value of desserts can be done by regulating the chemical composition of raw materials and using of dietary supplements. The article shows available options to increase quality of desserts, while using dietary supplement "Mipro-VIT» for the chocolate fondant. After made a research regarding the influence of dietary supplement "Mipro-VIT» was revealed the enrichment of mineral, vitamins and proteins in the dessert.As a result,the nutritional value of product was improved.Final results, which is based on the data obtained from the calculation of the complex quality indicator of chocolate fondant with dietary supplement «Mipro- 
$V I T »$, show, that dessert has higher complex indicator of value, than the main sample: main sample $-0,44$, sample based on the research-0,68.

Key words: quality;dessert; technology; chocolate fondant; dietary supplement «Mipro-VIT».

Статья відправлена: 28.12.2020 p. (C) Пересічна C.M. 